This is an author generated post-print of the article:

Monteiro, A., Sá, E., Fernandes, A., Gama, C., Sorte, S., Borrego, C., Lopes, M., Russo, M., 2018. How healthy will be the air quality in 2050? Air Quality, Atmosphere and Health 11, 353362.

The final publication is available on http://dx.doi.org/10.1007/s11869-017-0466-z 


\title{
How healthy will be the air quality in 2050 ?
}

\author{
A. Monteiro*, E. Sá, A. Fernandes, C. Gama, S. Sorte, M. A. Russo, C. Borrego, M. Lopes \\ CESAM, Department of Environment and Planning, University of Aveiro, 3810-193 Aveiro, Portugal. \\ *Corresponding author: alexandra.monteiro@ua.pt, Tel: +351 234370220, Fax: +351 234370309
}

\begin{abstract}
The air quality standards defined by the World Health Organization (WHO), and updated in 2005, continue to be much more exigent than current EU legislation, namely regarding the most critical pollutants over Europe: ozone $\left(\mathrm{O}_{3}\right)$ and particulate matter (PM10 and PM2.5).

This work intends to evaluate the fulfilment of these WHO standards in the present and in the future, including climate change effects. This study will be focused on Portugal, where each year the $\mathrm{O}_{3}$ and PM10 concentrations exceed the legislated limit values. For this, regional air quality simulations for present and future periods were conducted, with CAMx version 6.0, to investigate the impacts of climate change and anthropogenic emission projections on air quality over Portugal in 2050. The climate and emission projections for 2050 were derived from the Representative Concentrations Pathway 8.5 scenario.

Modelling results show that, over Portugal, the WHO standards are already not being fulfilled and will continue to be surpassed in the future. When considering climate change and projected anthropogenic emissions and comparing them to the actual scenario, a reduction in the maximum 8-hr daily $\mathrm{O}_{3}$ concentration is expected. For PM, the results indicate serious problems regarding the health impact expected for both long-term and short-term exposure. The annual averages for both PM10 and PM2.5 exceed the AQG over the country. The PM short-term exposure is already very high for current conditions and higher impacts are expected for future scenario, in particular regarding the PM10 values.

This air quality degradation is caused by the warmer and dryer conditions and the increase of background concentrations of pollutants expected for the 2050 climate. The results evidence that human health protection will be even more critical in the future, particularly for particulate matter. Furthermore, urgent air quality management strategies need to be designed, with transboundary cooperation and implementation.
\end{abstract}

KEYWORDS: air quality; WHO guidelines; human health effects; future scenarios; emission projection; climate projections. 


\section{INTRODUCTION}

The WHO air quality guidelines (AQGs) are intended for worldwide use and have been developed to support actions to achieve air quality that protects public health in different contexts (WHO, 2006). Nevertheless, countries have defined air quality standards to protect the public health of their citizens which do not necessarily follow the AQGs defined by the WHO (Bachmann, 2008; Vahlsing and Smith, 2012). National standards vary according to the approach adopted for balancing health risks, technological feasibility, economic considerations and various other political and social factors, which in turn depend on, among other things, the level of development and national capability in air quality management (Monteiro et al., 2016).

These AQGs are based on the most recent scientific evidence relating to air pollution and its health consequences. Although this information base has gaps and uncertainties, it offers a strong foundation for the recommended guidelines (Krzyzanowski and Cohen 2008). Several key findings that have emerged in recent years evidence that both ozone $\left(\mathrm{O}_{3}\right)$ and particulate matter (PM) have associated risks to health at concentrations currently found in many cities in developed countries (WHO 2006). Moreover, since researchers have not identified thresholds below which adverse effects do not occur, it must be stressed that these guideline values cannot fully protect human health. Secondly, an increasing range of adverse health effects has been linked to air pollution, and at ever-lower concentrations, in particular for particulate matter. The last revision of the WHO AQG for Europe provides new guideline values for these two pollutants $\left(\mathrm{O}_{3}\right.$ and $\left.\mathrm{PM}\right)$. In addition to the guideline values, interim targets are defined for each pollutant, which are proposed as incremental steps for a progressive reduction of air pollution and are intended for use in areas where pollution is high. These targets aim to promote a shift from high air pollutant concentrations, which have acute and serious health consequences, to lower concentration values.

The purpose of this work is to evaluate how these WHO AQGs are fulfilled over Portugal, for both present and future perspectives. These future scenario/projections of air quality should account for changes in both future emissions and climate due to their closely-coupled impacts on air quality (Penrod et al. 2014). Major pollutants, such as $\mathrm{O}_{3}$ and PM, are sensitive to changes in climate, which can potentially affect wet and dry deposition, chemical production, natural emissions and background concentrations (Jacob and Winner 2009). On the other hand, since changes in emissions of primary air pollutants and the precursors of secondary pollutants will lead to changes in air quality, sufficiently realistic emission scenarios must also be used (Penrod et al. 2014; Zlatev and Moseholm 2008). Numerical modelling represents a powerful 
tool to assess the influence of future climate scenarios on air pollutant concentrations and, consequently, on air quality management (Carvalho et al. 2010). There are different approaches to study air quality under future climate based on air quality modelling systems. In terms of emission scenarios, most of the studies conducted so far perform the future-year simulations based on the IPCC scenarios developed in the recent years: IPCC IS92 (Langner et al. 2005); IPCC SRES scenarios (Doherty et al. 2013; Jiang et al. 2013; Manders et al. 2012; Nolte et al. 2008; Penrod et al. 2014; Tagaris et al. 2007; Trail et al. 2014); and IPCC RCP (Representative Concentration Pathways) scenarios (Coleman et al. 2013; Gao et al. 2013; Lacressonnière et al. 2014). Additionally, there are studies that, while considering the IPCC scenarios, also considered the IIASA emission scenarios (MFR and CLE) and performed a comparison of the obtained results (Dentener et al. 2005; Stevenson et al. 2006).

To evaluate the combined impact of climate change and anthropogenic emissions on air quality, simulated changes in future air quality in Europe were already performed for the 2030s and 2050s, under the RCP8.5 scenario (Lacressonnière et al. 2014). In particular over Portugal, in the scope of the CLICURB project (Sá et al. 2016), high-resolution air quality simulations were performed for Portugal domain, forced by different (present and future) climate scenarios. These simulations were performed with the WRF-CAMx modelling system, already extensively tested over this study region and exhibiting a good behaviour (Ferreira et al. 2006; Martins et al. 2010; Martins 2012; Sá et al. 2016).

This study intends to use these numerical simulations, performed at a high spatial resolution, to evaluate where the WHO standards are exceeded, and compare current and future scenarios. The work is structured as follows. Section 2 describes the modelling system and the simulations setup for the current and future periods. The modelling results are discussed in Section 3. The summary and conclusions are given in Section 4.

\section{THE MODELLING SYSTEM}

This section describes the air quality modelling system, its characteristics, input data and setup for the current applications.

\subsection{Atmospheric pollutant emissions}

Emissions of primary air pollutants and precursors were determined for the two simulation periods. For the REF scenario, a top-down methodology was applied to disaggregate the 
anthropogenic emissions, using the up-to-date Portuguese national emission inventory (INERPA) (APA 2014). This inventory provides quantitative information for the main atmospheric pollutants: $\mathrm{CO}, \mathrm{NOx}, \mathrm{SOx}, \mathrm{NMVOC}, \mathrm{NH}_{3}, \mathrm{PM} 10$ and PM2.5, with total national emissions reported for 11 main source categories (SNAP). These annual national emissions, for each pollutant and activity sector, were spatially disaggregated to the sub-municipality level (Sá et al. 2016). For the traffic sector (SNAP7), a mixed methodology combining bottom-up and top-down methodology was applied: emissions from highways and major roads were estimated using a bottom-up approach, as line sources, and then converted to the model grid; a top-down methodology was applied to estimate emissions from other roads using national values and the municipality fuel consumption as a disaggregation factor.

For future emissions, the EmiPro-RCP model (Sá et al. 2015) was applied for the year 2050 under the RCP8.5. The model is a software package, based on Python language, to estimate the emission projections for several study regions. EmiPro-RCP is a user-friendly, PC-based model that can be used in Windows or Linux environments. It has the information from the RCP database about the emissions projections of the four RCPs for six different regions, for several GHG and other common air pollutants, from 2000 to 2100. The EmiPro-RCP require information about the study region, the study period and the specific scenario. In this case emissions for 2050 under the RCP8.5 were calculated. The EmiPro-RCP model (Sa et al., 2015), a software package based on Python language, was applied to estimate these emission projections. With the information about the study region, the study period and the chosen scenario, the model calculates the factors that will be multiplied by the current emissions in order to estimate the emissions for 2050 under the RCP8.5. More detail about these future emission data/projections can be found in Sá et al. (2016).

\subsection{Air quality modelling and setup}

The WRF - Weather Regional Forecasting model was used to downscale global climate simulations, performed by the Earth Systems Model MPI-ESM-LR, forced only by the greenhouse gases concentrations (Brands et al. 2013). Three online nested domains covering part of the North Atlantic and Europe were used, with resolutions of $81 \mathrm{~km}, 27 \mathrm{~km}$ and $9 \mathrm{~km}$ for the innermost domain covering the Iberian Peninsula. Two simulation periods were studied: (i) historical and (ii) medium-term future. For the future simulations, the IPCC greenhouse gas concentration scenario RCP8.5 was adopted. The RCP8.5 scenario combines assumptions about high populations and relatively slow income growths, with modest rates of technological change and energy intensity improvements, leading to long-term high energy demand and GHG 
emissions in absence of climate change policies. Compared to the total set of Representative Concentration Pathways (RCPs), RCP8.5 thus corresponds to the pathway with the highest greenhouse gas emissions, and is therefore more pessimistic (Riahi et al. 2011). For a detailed description of this downscaling approach and modelling configuration and validation, see Marta-Almeida et al. (2016). These WRF simulations were applied to a 5-year historical period (REF scenario: 2001-2005) and to a 5-year future period (FUT scenario: 2046-2050) for the Portugal domain with 9x9 $\mathrm{km}^{2}$ resolution (see Figures 1-3).

The meteorological outputs from the WRF application with MPI-ESM-LR are used as inputs for the chemistry-transport model CAMxv6.0. CAMx is an Eulerian photochemical dispersion model that considers the emission, dispersion, chemical reaction, and removal of pollutants in the troposphere by solving the pollutant continuity equation for each chemical species (Morris et al. 2004). The CAMx vertical structure included 15 layers (with the first layer having a $20 \mathrm{~m}$ thickness) and, in terms of chemical mechanism, the gas-phase photochemistry was resolved through the Carbon Bond (CB5) (Yarwood et al. 2005). The model also contains detailed algorithms for the relevant processes, including aqueous chemistry (RADM-AQ), inorganic aerosol thermodynamics/partitioning (ISORROPIA) and secondary organic aerosol formation/partitioning (SOAP). Initial and boundary conditions for both gases and particulate species were driven by the MOZART4 climatological model (Emmons et al. 2010). For the future simulations, the MOZART4 initial and boundary conditions were estimated based on the results of the LMDZ-INCA model for (Szopa et al. 2013).

This modelling system was already evaluated in several previous studies (Ferreira et al. 2006; Martins et al. 2010; Martins 2012) and this particular application for the reference scenario was evaluated using the DELTA tool developed in the scope of the FAIRMODE framework (Thunis et al. 2012; http://fairmode.jrc.ec.europa.eu). Results indicate that the model performs well in simulating concentrations of $\mathrm{NO}_{2}, \mathrm{O}_{3}$ and PM10, presenting a positive behaviour for all parameters in the DELTA tool, in terms of both time and space (Sá et al. 2016).

\section{RESULTS AND DISCUSSION}

In this section, the air quality modelling results for both scenarios (REF and FUT) as well as the main critical pollutants regarding the WHO AQG, namely $\mathrm{O}_{3}$ and PM (PM10 and PM2.5), are explored. A comparative analysis between the two scenarios is performed, followed by a spatial analysis and discussion about the exceedances of the AQG and its associated human health effects. 
In order to evaluate the impact of the different pollutants on human health, the distribution of the population in Portugal is presented in Figure 1.

Fig. 1. Population (number of inhabitants) in Portugal (Census, 2011).

\subsection{Ozone $\left(\mathrm{O}_{3}\right)$}

Recent studies have shown health effects at $\mathrm{O}_{3}$ concentrations below the previous guideline of $120 \mu \mathrm{g} . \mathrm{m}^{-3}$ but without clear evidence of a threshold (WHO 2006). Due to this, the WHO has changed the AQG for ozone from the existing level of $120 \mu \mathrm{g} \cdot \mathrm{m}^{-3}$ to $100 \mu \mathrm{g} \cdot \mathrm{m}^{-3}$ (daily maximum 8-hour mean). Apart from this AQG, the WHO settled an Interim level (associated with an increase in the number of attributable deaths) and a "high level" standard responsible for significant health effects (based on the findings of a large number of clinical inhalation and field studies) - see Table 1.

Table 1. Air quality guidelines for ozone (source: WHO 2006; EU Directive)

\begin{tabular}{|c|c|l|}
\hline & $\begin{array}{c}\text { Daily } \\
\text { maximum 8-h } \\
\text { mean }\left(\boldsymbol{\mu g} \cdot \mathbf{m}^{-3}\right)\end{array}$ & \multicolumn{1}{c|}{ Observations } \\
\hline High levels & 240 & $\begin{array}{l}\text { Significant health effects; substantial proportion of } \\
\text { vulnerable populations affected. }\end{array}$ \\
\hline $\begin{array}{c}\text { Interim target-1 } \\
\text { (IT-1) }\end{array}$ & 160 & $\begin{array}{l}\text { Important health effects; does not provide adequate } \\
\text { protection of public health. } \\
\text { Exposure to this level of ozone is associated with: } \\
\text { - physiological and inflammatory lung effects in healthy } \\
\text { exercising young adults exposed for periods of } 6.6 \text { hours; } \\
\text { - health effects in children (based on field studies) } \\
\text { - an estimated 3-5\% increase in daily mortality a (based } \\
\text { on findings of daily time-series studies). }\end{array}$ \\
\hline $\begin{array}{c}\text { Air quality } \\
\text { guideline } \\
\text { (AQG) }\end{array}$ & $\mathbf{1 0 0}$ & $\begin{array}{l}\text { Provides adequate protection of public health, though } \\
\text { some health effects may occur below this level. Exposure } \\
\text { to this level of ozone is associated with: } \\
\text { - an estimated 1-2\% increase in daily mortality a (based } \\
\text { on findings of daily time-series studies). } \\
\text { - extrapolation from chamber and field studies based on } \\
\text { the likelihood that real-life exposure tends to be repetitive } \\
\text { and chamber studies exclude highly sensitive or clinically } \\
\text { compromised subjects, or children. } \\
\bullet \text { likelihood that ambient ozone is a marker for related } \\
\text { oxidants. }\end{array}$ \\
\hline Target value & $\mathbf{1 2 0}$ & \\
\hline
\end{tabular}


The modelling results for the $26^{\text {th }}$ maximum 8 -h mean concentration of $\mathrm{O}_{3}$, regarding present (REF) and future (FUT) scenarios, are shown in Figure 2. An annual average was calculated from the 5-year simulation period (considering the average of the 5 annual averages). The colour scale was defined according to the levels settled by WHO.

Fig. 2. $\mathrm{O}_{3}$ modelling results for reference (REF) and future (FUT) scenarios, considering the $26^{\text {th }}$ maximum daily 8 -h mean.

When comparing both scenarios, it is expected that the $26^{\text {th }}$ highest maximum $\mathrm{O}_{3} 8-\mathrm{hr}$ daily value will decrease almost 5\% for inland Portugal in future conditions (FUT). The highest reductions located inland can be justified by the reduction of ozone precursors in the 2050 emission projections (namely $50 \%$ for NOx and $43 \%$ for VOC) with even higher reductions over the main urban areas and coastal zone (Sá et al. 2016), where the population density is higher (Figure 1).

Regarding the WHO standards, there is exceedance of the AQG over all the Portuguese territory for both scenarios, with higher exposure levels in the current scenario (but below the Interim target (IT-1)). This surpass is not verified when we analyse the legislation (Directive 2008/50/EC) compliance: the target value $\left(120 \mu \mathrm{g} \cdot \mathrm{m}^{-3}\right)$ is fulfilled for both conditions, with the exception of specific areas in the reference scenario, namely interior north and south west coast, where there is a lower population density (see Figure 1).

\subsection{Particulate Matter (PM10 and PM2.5)}

The range of health effects associated to air pollution is broad, but are predominantly of the respiratory and cardiovascular systems. The risk for various outcomes has been shown to increase with exposure and there is little evidence to suggest a threshold below which no adverse health effects would be anticipated. To assist this process, the AQG and interim target values settled by the WHO reflect the concentrations at which increased mortality responses, due to PM air pollution, are expected based on current scientific findings (WHO 2006). Besides the guideline value, three interim targets (IT) are defined for both PM10 and PM2.5 (see Table 2 
for long-term exposure and Table 3 for short-term). These interim targets can be particularly helpful for countries in gauging progress over time in the difficult process of steadily reducing population exposures to PM.

Table 2. Air quality guidelines for PM (annual mean) (source: WHO 2006; EU Directive)

\begin{tabular}{|c|c|c|l|}
\hline & $\begin{array}{c}\text { PM10 } \\
\left(\boldsymbol{\mu g . m} \mathbf{- n}^{-3}\right)\end{array}$ & $\begin{array}{c}\text { PM2.5 } \\
\left(\boldsymbol{\mu g . \mathbf { m } ^ { - 3 } )}\right.\end{array}$ & \multicolumn{1}{c|}{ Observations } \\
\hline $\begin{array}{c}\text { Interim target-1 } \\
\text { (IT-1) }\end{array}$ & 70 & 35 & $\begin{array}{l}\text { These levels are associated with about a 15\% higher } \\
\text { long-term mortality risk relative to the AQG level } \\
\text { (corresponding to the highest mean concentrations } \\
\text { reported in studies of long-term health effects). }\end{array}$ \\
\hline $\begin{array}{c}\text { Interim target-2 } \\
\text { (IT-2) }\end{array}$ & 50 & 25 & $\begin{array}{l}\text { These levels lower the risk of premature mortality } \\
\text { by approximately 6\% [2-11\%] relative to IT-1 level. }\end{array}$ \\
\hline $\begin{array}{c}\text { Interim target-3 } \\
\text { (IT-3) }\end{array}$ & 30 & 15 & $\begin{array}{l}\text { These levels reduce the mortality risk by } \\
\text { approximately 6\% [2-11\%] relative to IT-2 level. }\end{array}$ \\
\hline $\begin{array}{c}\text { Air quality } \\
\text { guideline } \\
\text { (AQG) }\end{array}$ & $\mathbf{2 0}$ & $\mathbf{1 0}$ & $\begin{array}{l}\text { The lowest levels at which total, cardiopulmonary } \\
\text { and lung cancer mortality have been shown to } \\
\text { increase with more than 95\% confidence in response } \\
\text { to long-term exposure to PM2.5. }\end{array}$ \\
\hline $\begin{array}{c}\text { Limit value } \\
\text { (EU Directive) }\end{array}$ & $\mathbf{4 0}$ & $\mathbf{2 5}$ & \\
\hline
\end{tabular}

The modelling results obtained for PM10 and PM2.5 annual averages, for the reference and future scenarios, respectively, are presented in Figure 3. An annual average was calculated from the 5-year simulation period for both scenarios (REF and FUT).

Fig. 3. PM10 (a) and PM2.5 (b) annual mean results for the reference (REF) and future (FUT) scenarios.

In the future scenario an increase of PM10 and PM2.5 annual mean levels over Portugal are expected, reaching $30 \%$ in the north and more than $40 \%$ in the south of the domain. However, this increase is mainly due to the boundary conditions of the MOZART model. The projections of RCP8.5 for 2050 indicate an increase of MOZART concentrations in terms of dust, which could support this increase in PM10 concentrations (Sá et al. 2016).

The fulfilment of the WHO AQGs is compromised over all the territory (in both high and low population density regions) in the current scenario, but is particularly critical for future 
conditions. In the future it is expected that even the IT-1 target will be surpassed in terms of long-term exposure, with serious mortality risk compared to the AQG level. This future situation is even more critical for PM2.5 for which exceedances of IT-1 are expected over 1 Portugal. Regarding legislation, the reference scenario is compliant regarding PM10, but will also surpass the limit for future conditions and for PM2.5.

In order to analyse and to interpret in more detail the results obtained, a seasonal analysis was made. Figure 4 presents the PM10 and PM2.5 averages over the summer (April-September) and winter (November- February) periods, for both current and future scenarios.

Fig. 4. Summer and winter average of (a) PM10 and (b) PM2.5, for REF and FUT scenarios

In general the PM concentrations are higher in summer than in winter (in both scenarios) which is justified by large presence of dust in the summer period (Monteiro et al., 2015) and low precipitation regimes.

Regarding the differences between the scenarios, the results are interesting: PM10 winter averages are higher in the future scenario, as it was already verified for the PM10 annual mean, however, a reduction of mean values of the concentration is expected during the summer under future conditions, which can be explained by the climatic scenario (less precipitation, high temperature). The same conclusions are extended to the PM2.5 seasonal mean values (Figure $4 b)$.

The WHO also defined indicators for the short-term exposure related to particulate matter, as seen in Table 3 (together with the legislated limits).

Table 3. Air quality guidelines for PM (daily mean) (source: WHO 2006; EU Directive)

\begin{tabular}{|c|c|c|l|}
\hline & $\begin{array}{c}\text { PM10 } \\
\left(\boldsymbol{\mu g . m ^ { - 3 }}\right)\end{array}$ & $\begin{array}{c}\text { PM2.5 } \\
\left(\boldsymbol{\mu g . \mathbf { g } ^ { - 3 } )}\right.\end{array}$ & \multicolumn{1}{c|}{ Observations } \\
\hline $\begin{array}{c}\text { Interim target-1 } \\
\text { (IT-1) }\end{array}$ & 150 & 75 & $\begin{array}{l}\text { Based on published risk coefficients from multi- } \\
\text { centre studies and meta-analyses (about 5\% increase } \\
\text { of short-term mortality over AQG value) }\end{array}$ \\
\hline $\begin{array}{c}\text { Interim target-2 } \\
\text { (IT-2) }\end{array}$ & 100 & 50 & $\begin{array}{l}\text { Based on published risk coefficients from multi- } \\
\text { centre studies and meta-analyses (about 2.5\% } \\
\text { increase of short-term mortality over AQG value) }\end{array}$ \\
\hline Interim target-3 & 75 & 37.5 & Based on published risk coefficients from multi- \\
\hline
\end{tabular}




\begin{tabular}{|c|c|c|l|}
\hline (IT-3) & & & $\begin{array}{l}\text { centre studies and meta-analyses (about 1.2\% } \\
\text { increase in short-term mortality over AQG value). }\end{array}$ \\
\hline $\begin{array}{c}\text { Air quality } \\
\text { guideline (AQG) }\end{array}$ & $\mathbf{5 0}$ & $\mathbf{2 5}$ & $\begin{array}{l}\text { Based on relationship between 24-hour and annual } \\
\text { PM levels. }\end{array}$ \\
\hline $\begin{array}{c}\text { Limit value } \\
\text { (EU Directive) }\end{array}$ & $\mathbf{5 0}$ & - & 35 days exceedances allowed \\
\hline
\end{tabular}

The modelling results were post-processed in order to estimate the number of days with expected exceedance of the daily mean guidelines (AQG), for both PM10 and PM2.5 concentrations. Figure 5 shows these results for the reference (REF) and future (FUT) scenarios.

Fig. 5. Number of days with exceedance of the WHO guideline for daily average of (a) PM10 and (b) PM2.5 for reference (REF) and future (FUT) scenarios.

In terms of short-term exposure (daily-mean levels), and in contrary to the long-term results, the situation is more aggravating regarding PM10 exposure than for PM2.5. In the current scenario more than $50 \%$ of the days are expected to exceed the AQG for PM10, and more than $80 \%$ of the days in the future scenario. For PM2.5 this percentage of the days with exceedance is lower (around 20\% in REF and 50\% in FUT).

\section{SUMMARY AND CONCLUSIONS}

The main objective of this study is to investigate how the AQGs defined by the WHO are fulfilled under present and future conditions over Portugal. To achieve this goal the CAMx chemistry-transport model, forced by the WRF meteorological outputs, was used to produce the pollutants concentration expected for the present and future (2050) scenarios.

Modelling results pointed out that regarding $\mathrm{O}_{3}$, the WHO AQGs are already not being fulfilled but a reduction is expected in the future scenario, although not sufficient to meet the AQG criteria. For PM, the results indicate serious problems regarding the health impact expected for both long-term and short-term exposure, in particular for the future scenario. The annual average for both PM10 and PM2.5 exceed the AQG over all of Portugal, with the surpass of the IT-1 target in the southern region, in particular for the future scenario (which is justified by the RCP projections of dust increase). The seasonal analysis indicates that the increase of the PM concentration values is mainly linked to the winter season (residential combustion emissions). 
The PM short-term exposure is already very high for current conditions with higher impacts for the future scenario (more than 50\%-80\% of the days above the AQG), and in particular regarding the PM10 values.

These results can be key to support current and future air quality management. The design and implementation of mitigation plans by regional/national authorities and policy-makers have to take into account the current scenario, together with the emission projections and climate change impacts. Only this integrated analysis can promote a successful progress towards the AQG fulfilment and health risk reduction in all areas.

\section{ACKNOWLEDGEMENTS}

The authors wish to thank the financial support of FEDER through the COMPETE Programme and the national funds from FCT - Science and Technology Portuguese Foundation for financing the CLICURB project (EXCL/AAG-MAA/0383/2012), in which we appreciate warm help given by Dr. Martinho Almeida and Dr. Alfredo Rocha for the meteorological simulations performed, and also the AIRSHIP project (PTDC/AAG-MAA/1581/2014; POCI-01-0145FEDER-016708), DOUROZONE project (PTDC/AAG-MAA/3335/2014; POCI-01-0145FEDER-016778) and the Ph.D. grants of A. Fernandes (SFRH/BD/86307/2012) and C. Gama (SFRH/BD/87468/2012). Thanks are also due, for the financial support to CESAM (UID/AMB/50017), to FCT/MEC through national funds, and the co-funding by the FEDER, within the PT2020 Partnership Agreement and Compete 2020.

\section{REFERENCES}

APA (Portuguese Environmental Agency) (2014) Portuguese informative inventory report 1990-2012. Submitted under the UNECE convention on long-range transboundary air pollution. Agência Portuguesa do Ambiente (Ed.), Amadora, Portugal, March 2014

Bachmann J (2008) WHO... and why. Air Qual Atmos Health 1, 15-16. Doi:10.1007/s11869008-0011-1

Brands S, Herrera S, Fernandez J, Gutierrez J M (2013) How well do CMIP5 Earth System Models simulate present climate conditions in Europe and Africa? A performance comparison for the downscaling community. Clim Dynam 41:803-817 
Carvalho A, Monteiro A, Solman S, Miranda A I, Borrego C (2010) Climate-driven changes in air quality over Europe by the end of the 21 st century, with special reference to Portugal. Environ Sci Policy 13:445-458

Coleman L, Martin D, Varghese S, Jennings S G, O’Dowd C D (2013) Assessment of changing meteorology and emissions on air quality using a regional climate model: Impact on ozone. Atmos Environ 69:198-210

Dentener F, Stevenson D, Cofala J, Mechler R, Amann M, Bergamaschi P, Raes F, Derwent R (2005) The impact of air pollutant and methane emission controls on tropospheric ozone and radiative forcing: CTM calculations for the period 1990-2030. Atmos Chem Phys 5:1731-1755

Doherty R M, Wild O, Shindell D T, Zeng G, MacKenzie I A, Collins W J, Fiore A M, Stevenson D S, Dentener F J, Schultz M G, Hess P, Derwent R G, Keating T J (2013) Impacts of climate change on surface ozone and intercontinental ozone pollution: a multi-model study. $\mathrm{J}$ Geophys Res 118:3744-3763

Emmons L K, Walters S, Hess P G, Lamarque J-F, Pfister G G, Fillmore D, Granier C, Guenther A, Kinnison D, Laepple T, Orlando J, Tie X, Tyndall G, Wiedinmyer C, Baughcum S L, Kloster S (2010) Description and evaluation of the Model for Ozone and Related chemical Tracers, version 4 (MOZART-4). Geosci Model Dev 3:43-67

Ferreira J, Martins H, Monteiro A, Miranda A I, Borrego C (2006) Air quality modelling application to evaluate effects of PM air concentrations on urban population exposure. Epidemiology 17:S252-S253

Gao Y, Fu JS, Drake J B, Lamarque J F, Liu Y (2013) The impact of emission and climate change on ozone in the United States under representative concentration pathways (RCPs). Atmos Chem Phys 13:9607-9621

Jacob D J, Winner D A (2009) Effect of climate change on air quality. Atmos. Environ. 43: 5163

Jiang H, Liao H, Pye H O T, Wu S, Mickley L, Seinfeld J H, Zhang X (2013) Projected effect of 2000-2050 changes in climate and emissions on aerosol levels in China and associated transboundary transport. Atmos Chem Phys 13:7937-7960

Krzyzanowski M, Cohen A (2008) Update of WHO air quality guidelines. Air Qual Atmos Health 1:7-13. doi:10.1007/s11869-008-0008-9 
Lacressonnière G, Peuch V H, Vautard R, Arteta J, Déqué M, Joly M, Josse B, Marécal V, Saint-Martin D (2014) European air quality in the 2030s and 2050s: Impacts of global and regional emission trends and of climate change. Atmos Environ 92:348-358

Langner L, Bergstrom R, Foltescu V (2005) Impact of climate change on surface ozone and deposition of sulphur and nitrogen in Europe. Atmos Environ 39:1129-1141

Manders A, van Meijgaard E, Mues A, Kranenburg R, van Ulft L, Schaap M (2012) The impact of differences in large-scale circulation output from climate models on the regional modeling of ozone and PM. Atmos Chem Phys 12:9441-9458

Marta-Almeida M, Teixeira J C, Carvalho M J, Melo-Gonçalves P, Rocha A M (2016) High resolution WRF climatic simulations for the Iberian Peninsula: Model validation. Phys Chem Earth 94:94-105

Martins H, Miranda A, Borrego C (2010) Atmospheric modelling under urban land use changes: meteorological and air quality consequences. $31^{\text {st }}$ NATO/SPS International Technical Meeting on Air Pollution Modelling and its Application, 27 Sept - 1 Oct., Torino, Italy

Martins H (2012) Urban compaction or dispersion? An air quality modelling study. Atmos Environ 54:60-72

Monteiro A, Fernandes AP, Gama C, Borrego C, Tchepel O (2015) Assessing the mineral dust from North Africa over Portugal region. Atmospheric Pollution Research 6, 70-81

Monteiro A, Vieira M, Gama C, Miranda A I (2016) Towards an improved air quality index. Air Quality, Atmosphere and Health. DOI: 10.1007/s11869-016-0435-y (in press)

Morris R E, Yarwood G, Emery C, Koo B (2004) Development and Application of the CAMx Regional One-Atmosphere Model to Treat Ozone, Particulate Matter, Visibility, Air Toxics and Mercury. $97^{\text {th }}$ Annual Conference and Exhibition of the A\&WMA, June 2004, Indianapolis

Nolte C G, Gilliland A, Hogrefe C, Mickley L (2008) Linking global to regional models to assess future climate impacts on surface ozone levels in the United States. J Geophys Res 113:D14307

Penrod A, Zhang Y, Wang K, Wu S Y, Leung L (2014) Impacts of future climate and emission changes on U.S. air quality. Atmos Environ 89:533-547 
Riahi K, Rao S, Krey V, Cho C, Chirkov V, Fisher G, Kindermann G, Nakicenovic N, Rafaj P (2011) RCP 8.5 - A scenario of comparatively high greenhouse gas emissions. Climatic Change 109:33-57

Sá E, Ferreira J, Carvalho A, Borrego C (2015) Development of current and future pollutant emissions for Portugal. Atmos Pollut Res 6:849-857

Sá E, Martins H, Ferreira J, Marta-Almeida M, Rocha A, Carvalho A, Freitas S, Borrego C (2016) Climate change and pollutant emissions impacts on air quality in 2050 over Portugal. Atmos Environ 131:209-224

Stevenson D, Dentener F, Schultz M, Ellingsen K, van Noije T, Wild O, Zeng G, Amann M, Atherton C, Bell N, Bergmann D, Bey I, Butler T, Cofala J, Collins W, Derwent R, Doherty R, Drevet J, Eskes H, Fiore A, Gauss M, Hauglustaine D, Horowitz L, Isaksen I., Krol M, Lamarque J-F, Lawrence M, Montanaro V, Müller J-F, Pitari G, Prather M, Pyle J, Rast S, Rodriguez J, Sanderson M, Savage N, Shindell D, Strahan S, Sudo K, Szopa S (2006) Multimodel ensemble simulations of present-day and near-future tropospheric ozone. J Geophys Res 111:D08301

Szopa S, Balkanski Y, Schulz M, Bekki S, Cugnet D, Fortems-Cheiney A, Turquety S, Cozic A, Déandreis C, Hauglustaine D, Idelkadi A, Lathière J, Lefevre F, Marchand M, Vuolo R, Yan N, Dufresne J-L (2013) Aerosol and ozone changes as forcing for climate evolution between 1850 and 2100. Clim Dynam 40:2223-2250

Tagaris E, Manomaiphiboon K, Liao K, Leung L R, Woo J, He S, Amar P, Russell AG (2007) Impacts of global climate change and emissions on regional ozone and fine particulate matter concentrations over the United States. J Geophys Res 112:D14312

Thunis P, Pederzoli A, Pernigotti D (2012) Performance criteria to evaluate air quality modelling applications. Atmos Environ 59:476-482

Trail M, Tsimpidi AP, Liu P, Tsigaridis K, Rudokas J, Miller P, Nenes A, Hu Y., Russel A.G. (2014) Sensitivity of air quality to potential future climate change and emissions in the United States and major cities. Atmos Environ 94:552-563

Vahlsing C, Smith K R (2012) Global review of national ambient air quality standards for PM10 and SO2 (24 h). Air Qual Atmos Health 5:393-399. Doi:10.1007/s11869-010-0131-2

WHO (World Health Organization) (2006) Air quality guidelines for particulate matter, ozone, nitrogen dioxide and sulfur dioxide: global update 2005, Copenhagen, 484 pages 
Yarwood G, Rao S, Yocke M, Whitten G. (2005) Updates to the Carbon Bond Chemical Mechanism: CB05. Final Report to the US EPA, RT-0400675

Zlatev Z, Moseholm L (2008) Impact of climate change on pollution levels in Denmark. Ecol Model 217:305-332 